\title{
RANCANG BANGUN ELEKTROKARDIOGRAPH BERBASISKAN PERSONAL COMPUTER (PC)
}

\author{
Oleh \\ Salwin Anwar \\ Staf Pengajar Teknik Elektro Politeknik Negeri Padang
}

\begin{abstract}
Electrical signals of body are chemical's respond of specific cell type. Electrocardiograph is used to record heart electrical activity which flow around the chest. This electricity flow is responded by sensor which acts as conductor.

$A D 624 A D$ is an instrument amplifier which is designed to transducer application with low level and pressure transducer. AD624AD has high precisions with low noise and input offside voltage less than $0,25 \mu V^{\rho} \mathrm{C}$.

AD624AD not need pre-gain 1, 100, 200, 500 and 1000. An external resistor can be used to arrange the gain of AD624AD with level rating 1 up to 10.000

However, this equipment have input voltage to sensor 0,3 to $50 \mathrm{mV}$. The output voltage result from 1,6 to 5 volt using this amplifier.
\end{abstract}

Keyword: electrocardiograph, gain, $A D 624 A D$

\section{PENDAHULUAN}

Dengan ditemukannya alat pendeteksi sinyal biopotensial yang dihasilkan oleh tubuh manusia (sinyal denyut jantung) sangat berpengaruh terhadap perkembangan teknologi biomedika. Sinyal denyut jantung ini direkam menggunakan suatu alat yang disebut dengan Electrocardiograph (ECG) sehingga bisa digunakan sebagai indikasi normal atau tidaknya kondisi jantung seseorang.

Pada saat ini peralatan sejenis yang telah ada harganya masih relative mahal sehingga susah dijangkau oleh instansi-instansi kesehatan seperti rumah sakit. Disamping penggunaan komputer yang semakin luas, telah membawa kemajuan pada semua instansi untuk menggunakan alat pencatat data pasien atau sebagai peralatan pada administrasi perkantoran.
Pada awal perkembangannya instrumentasi ini dibuat dengan komponen-komponen analog, sehingga sinyal Electrocardiogram (ECG) yang diperoleh dari hasil pembrosesan secara analog. Dengan kemajuan teknologi dibidang Elektronika digital yang begitu cepat, sehingga dimungkinkan untuk merancang instrumentasi berbasis digital.Selanjutnyadengan perkembangan komputer juga mengalami kemajuan yang sangat pesat, sehingga memunculkan komputer-komputer yang memiliki kemampuan yang lebih baik.

Sehubungan dengan permasalahan tersebut pembuatan alat Electrocardiograph berbasiskan Personal Computer ini akan dapat memberikan pemecahan masalah bagi instansi-instansi kesehatan untuk memiliki peralatan Electrocardiograph.

Didalam jantung terdapat suatu mekanisme khusus yang menjaga irama 
jantung dan menjalarkan potensial aksi ke seluruh otot jantung untuk menimbulkan denyut jantung yang berirama.

Jantung dilengkapi dengan suatu sistem khusus untuk membangkitkan impuls-impuls ritmis yang menyebabkan timbulnya kontraksi ritmis otot jantung, dan untuk mengkonduksikan impuls ini dengan cepat keseluruh jantung.

Kebanyakan serat-serat jantung mempunyai kemampuan perangsangan sendiri (self-excitation), yang merupakan suatu proses yang dapat menyebabkan lepasan dan kontraksi ritmis yang otomatis. Hal ini memang benar bahwa serat-serat jantung merupakan sistem konduksi yang khusus; bagian sistem ini yang memperlihatkan ransangan sendiri secara luas adalah serat-serat nodus sinus. Dengan alasan inilah nodus sinus biasanya mengatur kecepatan denyut seluruh jantung.

Aksi yang direkam dari suatu serat nodus sinus untuk tiga denyut jantung, dengan perbandingan satu potensial aksi otot tunggal ventrikel. Perhatikan. bahwa potensial serat nodus sinus mempunyai muatan negatif antara lepasan hanya sebesar -55 sampai -60 milivolt, sedangkan serat ventrikel mempunyai potensial sebesar -85 samapi -90 milivolt.

Penyebab dari berkurangnya muatan negatif ini dalam membran sel serat sinus biasanya membocorkan ion-ion natrium.

Pada penelitian ini dirancang dan dibuat Electrocardiograph yang pemprosesan sinyalnya dilakukan secara digital. Pada pemprosesan sinyal ECG ini dilakukan pemfilteran. Dengan penggunaan filter 1 akan menghasilkan sinyal ECG yang cukup murni dan tidak terinterferensi oleh frekuensi jala-jala, frekuensi-frekuensi sinyal yang diakibatkan aktivitas organ tubuh lain serta sinyal pengganggu(noise) yang dapat menyebabkan sinyal yang didapat tidak murni. Hal tersebut bertujuan agar diagnosa kondisi jantung dapat dilakukan secara akurat.

Sedangkan untuk pemprosesan pada komputer digunakan software yang dibuat dengan menggunakan bahasa pemograman Delphi

\section{TEORI PENDUKUNG}

\section{Isyarat Listrik Tubuh}

Isyarat listrik (electrical signal) tubuh merupakan hasil perlakuan kimia dari tipe sel tertentu. Dengan mengukur isyarat listrik tubuh secara selektif sangat beerguna untuk memperoleh informasi klinik tentang fungsi tubuh.

Elektrokardiogram merupakan pencatat isyarat biolistrik jantung, dilakukan pada permukaan kulit

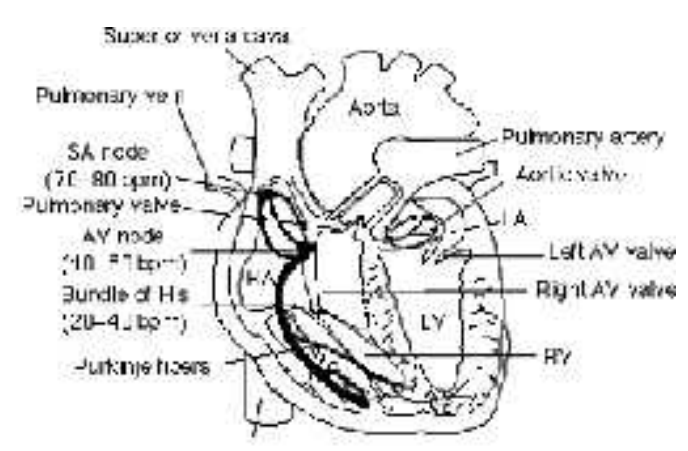

Gambar 1. Skema jantung manusia

Irama jantung diatur oleh isyarat listrik yang dihasilkan oleh ransiangan secara spontan, oleh sel-sel khusus yang terdapat apada atrium kanan (dekat muara vena cava superior dan inferior), yaitu SA.node (simpul sinotrial). SA node ini bertindak sebagai "pace maker"; bergetarnya SA node berkisar 72 kali permenit. Getaran tersebut dapat meningkat atau menurun diatur oleh saraf eksternal jantung yang merupakan respon atau jawaban kebutuhan darah oleh tubuh.

Isyarat listrik dari $S A$ node menyebabkab depolarisasi otot jantung atrium dan memompa darah keventrikel, kemudian diikuti oleh repolarisasi otot 
atrium dan memompa darah ke ventrikel, kemudian diikuti oleh repolarisasi otot atrium.

Isyarat listrik akan dilanjutkan ke AV node akan menyebabkan depolarisasi ventrikel kanan dan kiri yang menyebabkan kontraksi ventrikel sehingga darah dipompa ke dalam arteri pulmonalis dan ke aorta; saraf pada fentrikel dan otot ventrikel kemudian mengalami repolarisasi dan mulai kembali isyarat listrik dari $S A$ node.

Sewaktu impuls jantung melewati jantung, arus listrik akan menyebar kedalam jaringan disekeliling jantung, dan sebagian kecil dari arus listrik ini akan menyebar kesegala arah diseluruh permukaan tubuh. Bila pada kulit yang berlawanan dengan sisi jantung ditempatkan elektroda, maka potensial listrik yang dicetuskan oleh arus itu akan dapat direkam, rekaman ini yang dikenal sebagai elektrokardiogram.

Saraf dan dan otot jantung dapat dipandang sebagai sumber listrik tertutup dalam suatu konduktor listrik dada dan perut (torso). Hal ini nyata sekali tidak mungkin mengukur kelistrikan jantung secara lansung.

\section{Aliran Arus Listrik Mengelilingi Jantung Pada Dada}

Gambar 2. menunjukkan masa otot ventrikel yang terletak didalam dada. Sebenarnya jantung terendam dalam media yang konduktif. Bila satu bagian ventrikel menjadi lebih elektronegatif diabandingkan bagian yang lainnya, aliran listrik akan mengalir dari daerah yang terdepolarisasi menuju kedaerah yang terpolarisasi melalui jalur yang melingkar yang besar, seperti yang dilukiskan pada gambar ini. Dapat dikatakan bahwa arus listrik rata-rata yang bermuatan negatif mengalir ke basis jantung dan arus listrik rata-rata yang bermuatan positif akan mengalir ke bagian apeks.

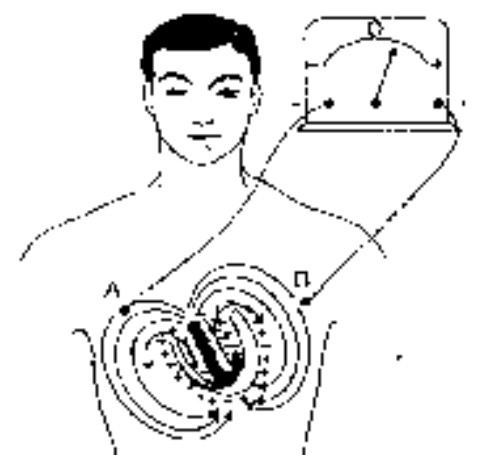

Gambar 2. Aliran listrik sekitar dada

\section{Analog To Digital Converter (ADC) 0809}

ADC 0809 berfungsi untuk mengubah sinyal analog menjadi sinyal yang ekivalen dalam bentuk digital. Resolusi suatu converter dinyatakan dalam bit. Resolusi menyatakan tingkat ketelitian suatu converter ADC, semakin tinggi tingkat ketelitiannya, semakin peka ADC terhadap perubahan masukan analognya. ADC 0809 merupakan jenis ADC yang memiliki resolusi 8 bit, maksudnya ADC jenis ini menghasilkan data digital sebanyak 8 bit (8 kanal terminal keluaran).

Pada ADC terjadi proses digitalisasi, yaitu pencuplikan, kuatitasi dan pengkodean. Hasil pengkodeaan dalam bentuk biner merupakan hasil konversi suatu ADC.

Gambar 3 berikut merupkan blok diagram dasar atau diagram fungsional dari ADC 0809.

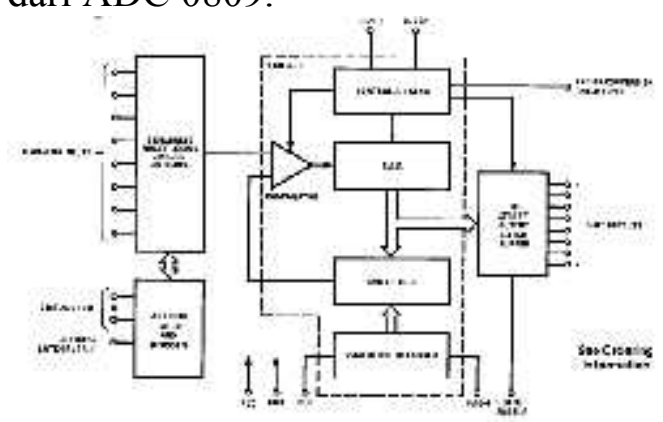

Gambar 3. Diagram funsional ADC 0809

Terlihat pada gambar 3 diatas bahwa ADC 0809 memiliki 8 (delapan) buah kanal input yaitu IN8 sampai dengan IN\&yang bisa digunakan salah 
satu atau semuanya. Pemilihan kanal input ini dilakukan dengan mengkombinasikan 3 bit alamat $\mathrm{C}, \mathrm{B}$, dan A yang terlihat pada table 1 berikut. Setelah input dipilih maka nilai alamat C, B dan A tersebut dikunci oleh Address Latch and decoder dengan memberikan isyarat Address Latch Enable (ALE).

Untuk mendigitalisasi sinyal secara benar digunakan teorema pencuplikan Nyquist yang menyatakan bahwa "Frekwensi pencuplikan lebih besar dua kali komponen frekwensi maksimum yang ingin dideteksi (diakuisisi). ADC digunakan untuk mencuplik beberapa kanal, maka laju efektif pencuplikan masing-masing kanal berbanding terbalik dengan jumlah kanal yang dicuplik, sesuai dengan persamaan berikut :

$$
\begin{array}{lll}
\text { Laju } & \text { Pencuplika } \quad \mathrm{n} \text { ADC } \\
\hline \text { Jumlah Kanal }
\end{array}
$$

Setelah pemilihan kanal input dilakukan, maka isyarat input analog yang dipilih siap untuk dikonversi, yaitu dengan memberikan isyarat Start Conversion (SC). Setelah konversi selesai, ADC 0809 akan mengeluarkan isyarat EOC (End Of Conversion). Untuk membaca hasil konversinya pada output, sebelumnya harus diberikan dahulu isyarat OE (Output Enable). Waktu yang dibutuhkan ADC untuk mengkonversi sinyal adalah $100 \mu s$. Proses ini akan dapat dilihat pada timing specification, yang terlihat pada gambar 4. dan timing diagram yang terlihat pada gambar 5 .

\begin{tabular}{|c|c|c|c|c|c|c|}
\hline s)t: & Pendin & artiks & $N_{1}$ & ip & Kes & Itis \\
\hline 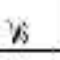 & 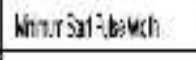 & hixs: & & $x_{1}$ & 8 & is \\
\hline WE & 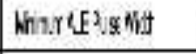 & haxf & & $x$ & 8 & is \\
\hline$\xi$ & 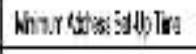 & harf & & $s$ & 5 & is \\
\hline$y$ & Nhar teds: odinx & harf & & $x$ & 6 & $\mathrm{~B}$ \\
\hline 0 & 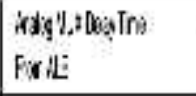 & 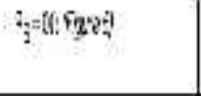 & & : & 3 & $\therefore$ \\
\hline Hits & CEarbC spica & 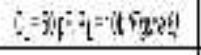 & & 3 & 80 & $B$ \\
\hline itt. & Cotrboh? & 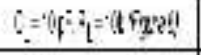 & & 3 & 8 & is \\
\hline 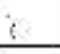 & Crascotrt & 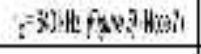 & 9! & $\cdot x$ & $\cdot 6$ & 5 \\
\hline$i$ & $0,6=0.35$ & & 11 & in & a) & 此 \\
\hline$w$ & Exoda & haxt & 1 & & $8+23$ & $\begin{array}{l}30.1 \\
30 \%\end{array}$ \\
\hline 6 & Lpliags: & rendlys & & 1 & 13 & $f$ \\
\hline $4 \pi$ & $\begin{array}{l}\text { FIst:avo } \\
\text { cosiax }\end{array}$ & ATSS:AYs & & 1 & $1 j$ & $f$ \\
\hline
\end{tabular}

Gambar 4. Timing specification ADC 0089

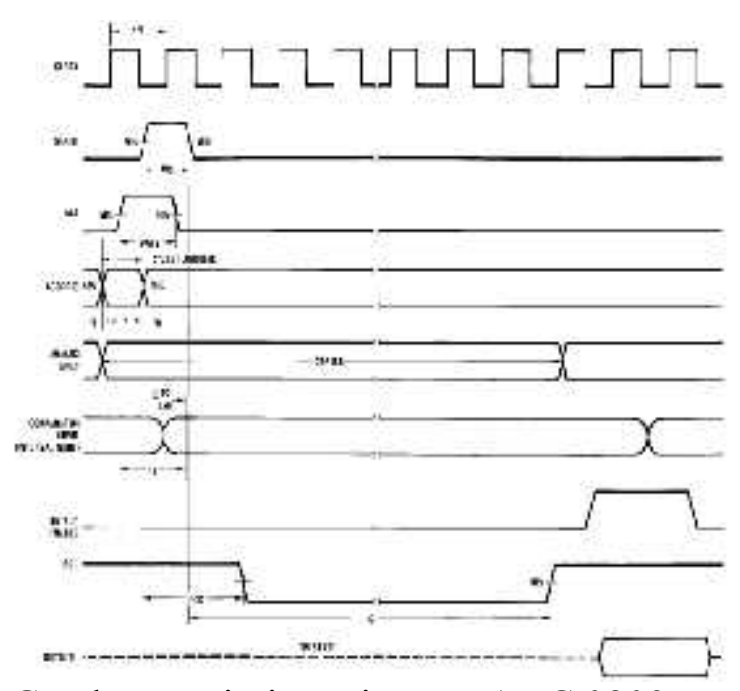

Gambar 5. Timing Diagram ADC 0809

Menentukan persamaan untuk mendapatkan tegangan hasil konversi ADC (desimal) dengan nilai maksimum ADC 8 bit (225) kemudian dikalikan dengan tegangan referensi ADC. Berikut bentuk persamaan dalam betuk matematika untuk tegangan keluaran 
(Vout):

$$
V_{\text {out }}=\frac{\text { Data Asli ADC }}{225} x \text { Tegangan_referensi }
$$

Untuk mendapatkan tegangan referensi kartu antar muka ADC, diberikan tegangan referensi pada kanal input card tersebut (salah satu atau semuanya) dengan kapasitas yang terus meningkat. Jika keluaran ADC tersebut berbeda pada nilai 225 (nilai desiamal $=$ 255), maka tregangan masukan yang diberikan tersebut merupakan tegangan referensi.

Keluaran ADC akan tetap berada pada nilai 255 meskipun diberi tegangan masukan yang lebih besar dari tegangan referensi.

Tegangan referensi didapat dengan menghubungkan +Vref ADC 0809 ke Vcc. Vcc adalah 5 Volt, maka nilai tegangan referensinya adalah sebesar 5 Volt, sehingga ADC 0809 mengeluarkan nilai decimal 255 untuk nilai tegangan input sebesar 5 Volt. Jika tegangan input melebihi dari tegangfan referensi untuk ADC 0809 akan tetap berada pada posisi 255 .

Suatu tujuan tercapai dengan bila dilakukan melalui tahap - tahap yang disusun dan dikerjakan dengan baik, seperti diagram yang akan dilakukan. Perancangan merupakan awal proses pembuatan suatu peralatan. Dalam proses perancangan suatu alat, ada tahaptahap penting yang bisa dilakukan yaitu pembuatan rangkaian dari setiap blok diagram yang sudah dirancangsebelumnya. Eksperimen rangkaian tersebut, perangkaian lay out dikertas millimeter, pembuatan lay out di $\mathrm{PCB}$, pemasangan komponen dan pembuatan box.

Pembuatan blok diagram merupakan langkah awal yang harus dilakukan dalam tahap perancangan. Diagram blok ini merupakan realisasi dari suatu ide, kemudian melangkah pada tahap berikutnya yaitu memilih komponen yang sesuai dengan spesifikasi alat yang akan dibuat. Selanjutnya tahap pembuatan rangkaian yang mengacu pada tahap percobaan rangkaian yang akan dilakukan di laboratorium. Tahap eksperimen rangkaian ini dilakukan tiap blok pada protoboard dengan tujuan agar mudah melacak kesalahan yang terjadi serta mudah memperbaikinya. Serta seluruh rangkaian tang teruji dan memenuhi standar yang diharapkan, kemudian digabungkan untuk diuji coba kembali fungsinya secara keseluruhan dalam bentuk unit yang terintegrasi. Jika pada tahap tersebut berhasil maka dilanjutkan dengan tahap-tahap berikutnya yaitu perancangan lay out di kertas millimeter, pembuatan lay out PCB dengan menggunakan ferroclorit dan pemasangan komponen/penyolderan kaki komponen, kemudian dilakukan uji coba untuk memastikan bahwa alat berfungsi dengan baik sesuai dengan standar yang direncanakan. Tahap terakhir adalah pembuatan box tempat alat/komponen disimpan agar terintegrasi dalam bentuk suatu sistem.

\section{Deskripsi Kerja}

Pada bagian ini akan dijelaskan
tentang penggunaan maupun
pengoperasian dari alat yang dibuat.
Namun untuk lebih mengertinya akan
peralatan ini untuk lebih dahulu dapat
diperhatikan blok diagram berikut:

Pada bagian ini akan dijelaskan tentang penggunaan maupun pengoperasian dari alat yang dibuat. Namun untuk lebih mengertinya akan diperhatikan blok diagram berikut : 


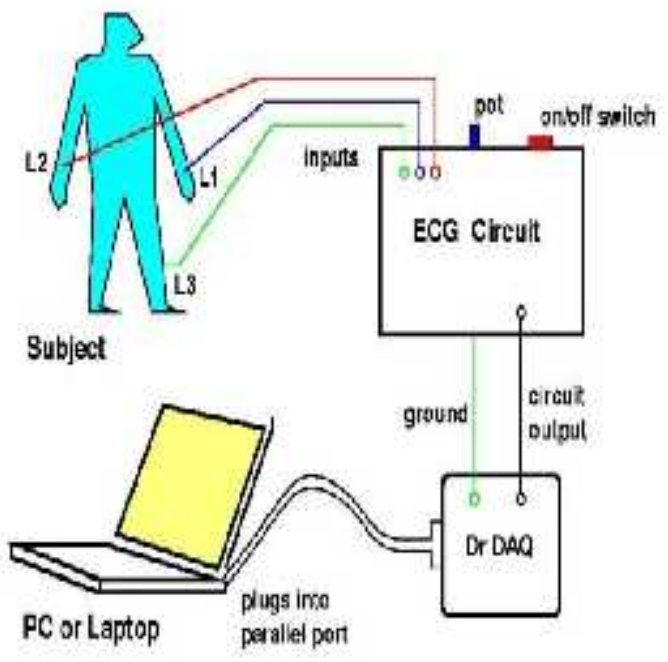

Gambar 6. Blok diagram EKG

\section{Perancangan Alat}

Pembuatan alat adalah merupakan tahap yang paling penting, hal ini akan tampak sejauh mana teori-teori yang akan dicapai secara maksimal dalam bentuk jadi. Pada tahap ini akan dijelaskan tentang pemilihan komponenkomponen dan peralihan rangkaian pendukung agar didapat alat yang sesuai dengan apa yang jadi tujuan, yaitu sebuah sistem dengan berbagai fungsi yang berbeda dengan faktor kesulitan yang kecil dalam pengoperasian tanpa mengurangi aspek-aspek perancangan yang telah diketahui keamanan, sistematika, ketersediaan komponen dan kegunaannya serta nilai teknologinya.

\section{Perancangan dan Pembuatan Hard ware}

Yang dikatakan komponen inti dari peralatan ini adalah komponen utama yang digunakan untuk perancangan alat ini, Subject merupakan hal terpenting dalam pemberian input. Subject yang digunakan merupakan manusia dengan kisaran umur 20-25 tahun. Kondisi subject dalam keadaan sehat ataupun dalam keadaan kurang sehat.

Pada subject akan dipasangakan sensor elektroda dengan jenis sensor dengan bentuk floating. Elektroda ini digunakan untuk mengukur potensial aksi dan untuk memindahkan transmisi ion kepenyalur elektron. Pemilihan jenis elektroda ini karena elektroda ini memiliki keuntungan dapat mencegah secara lansung antara logam dan kulit. Dibandingkan dengan elektroda lainnya elektroda ini cukup bagus digunakan. Sebagai perbandingannya dapat diperhatikan cara penggunaan dan pemasangan elektroda lainnya :

- Elektroda dengan bentuk plat, didaerah yang akan diletakkan elektroda digosokkan dengan saline solution (air garam fisiologis).

- Bentuk floating, diderah yang akan digunakan cukup hanya menempelkan elektroda saja tanpa mempergunakan cairan saline solution.

Adapun daerah lead (sadapan) elektroda dipergunakan sadapan anggota badan bipolar.

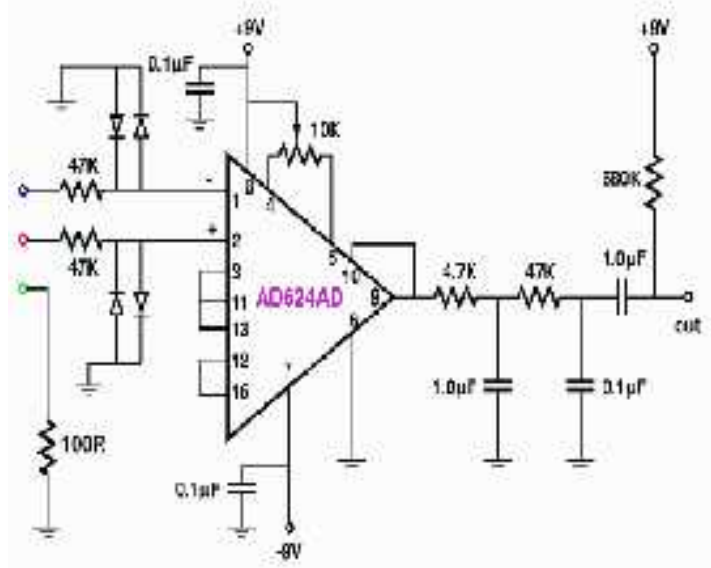

Gambar.7.Rangkaian sensor

\section{Input Kabel}

Karena penguat (amplifier) mengambil input dari masing-masing output elektroda. Maka sangat penting 
untuk memperhatikan jenis kabel yang akan digunakan. Kabel tersebut haruslah memiliki bahan konduktor yang baik.

Hal ini berfungsi dikarenakan input yang diambil dari output elektroda sangat kecil. Untuk mengetahui terminal hubungan elektroda dengan tubuh maka sebaiknya, kabel diberi perbedaan warna dengan warna merah sebagi terminal positif, kuning negatif dam grounding dengan warna hitam.

\section{HASIL DAN PEMBAHASAN}

Dalam pengujian sebaiknya dilakukan secar perblok dengan maksud untuk mengetahui apakah rangkaian yang dirancang pada blok tersebut dapat berjalan dengan baik. Blok diagram pada system ini diperlihatkan pada bab sebelumnya. Selain pengujian terhadap catu daya, maka pengujian selanjutnya dilakukan pada blok-blok berikutnya, yang pada sistem ini berisikan :

1. Pengujian program

2. Pengujian rangkaian catu daya

3. Pengujian rangkaian sensor

4. pengujian rangkaian interface

\section{Pengujian rangkaian catu daya}

Pada pengujian ini adapun tegangan input rangkaian ialah +9 Volt DC dan 9 Volt DC untuk rangkaian sensor. Sedangkan untuk rangkaian interface yang meliputi ADC (Analog Digital Converter) dipergunakan power supply dengan tegangan 5 Volt DC. Untuk rangkaian sensor sumber tegangan yang dipergunakan adalah baterai 9 Volt DC. Hal ini bertujuan untuk mendapatkan tegangan DC yang lebih murni untuk menghindari kebocoran tegangan dan untuk keselamatan.

Sedangkan untuk sumber tegangan pada rangkaian interface dipergunakan IC regulator 7805 sebagai pembatas tegangan.

\section{Pengujian Sensor}

Pada pengujian ini tegangan yang direspon oleh sensor sangat kecil yakni $0,3 \mathrm{mV}$. Jadi kondisi letak serta menempelnya sensor pada kulit tubuh sangat mempengaruhi. Hal ini dikarenakan, jika sadapan tidak erat maka sinyal listrik yang dideteksi oleh sensor akan sangat kecil, dikarenakan sinyal yang menyebar.

\section{Pengujian Rangkaian Amplifier}

Amplifier ini mengambil sinyal input melalui tiga buah sadapan elektroda. Besarnya sinyal input yang diambil melalui jantung sekitar $0,5 \mathrm{mV}$ sampai dengan $5 \mathrm{mV}$. Setiap output yang dihasilkan elektroda dipasangkan dioda, yang berfungsi untuk mengontrol atau mengamankan sinyal input positif dan sinyal input negatif yang akan menuju ke komponen analog divice (AD624AD).

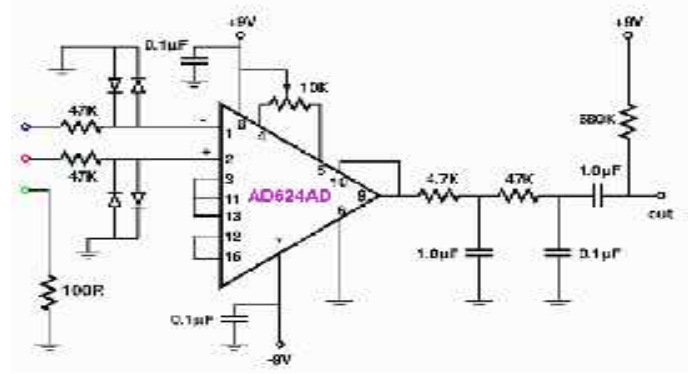

Gambar.8. Analog Divice AD624 AD AD6234AD ini memudahkan untuk memonitar sinyal yang dihasilkan oleh jantung. Hal ini dikarenakan sinyal input yang ditangkap oleh analog divece dapat dipekuat sampai dengan 1000 kali.

Penggunaan AD624AD ini dikarenakan ia memiliki kemampuan yang baik, adapun kemampuan tersebut adalah : 


\begin{tabular}{|ll|}
\hline $\begin{array}{l}\text { Supply } \\
\text { Voltage }\end{array}$ & $+-9 \mathrm{~V}$ Battery power \\
\hline Programmable & $1, \quad 100, \quad 200, \quad 500$, \\
Gain & 1000,2500 \\
\hline CMRR & $\begin{array}{l}130 \mathrm{~dB}(\text { Gain=500 to } \\
1000)\end{array}$ \\
\hline Gain & $25 \mathrm{MHz}$ \\
Bandwidth & \\
Product & \\
\hline Input offset & $25 \mu \mathrm{V}, \max$ \\
\hline
\end{tabular}

Dikarenakan nilai input yang tidak konstan, dapat dilogikakan jika penguatan diberikan maksimum yakni 1000 kali maka nilai outputnya adalah :

$$
\begin{aligned}
& \text { Vin }=0,5-5 \mathrm{mV} \\
& \begin{aligned}
\mathrm{G} & =1000 \\
\text { Vout } & =1000 \times 5 \mathrm{mV} \\
& =5 \mathrm{~V} \ldots \ldots \ldots . . . . . . . .
\end{aligned}
\end{aligned}
$$

nilai input tegangan maksimum $5 \mathrm{mV}$

$$
\begin{aligned}
\mathrm{I} \text { in } & =5 \mathrm{mV} / 16 \mathrm{ohm} \\
& =0,0003125 \mathrm{Amper}
\end{aligned}
$$

Vout $=2,6 \mathrm{mV} \times 1000$

$$
=2,6 \mathrm{~V}
$$

nilai input tegangan maksimum $2,6 \mathrm{mV}$

$$
\begin{aligned}
\operatorname{lin}=0,0026 / 16 \mathrm{ohm} \\
=0,0001625 \mathrm{Amper} \\
\text { Vout }=3,2 \mathrm{mV} \times 1000 \\
=3,2 \mathrm{mV} \ldots \ldots \ldots \ldots
\end{aligned}
$$

nilai input tegangan maksimum $3,2 \mathrm{mV}$

\begin{tabular}{|c|c|c|c|}
\hline $\begin{array}{l}\text { Vin } \\
(\mathrm{mV})\end{array}$ & In $(\mathrm{mA})$ & $\begin{array}{l}\text { Vout } \\
\text { (Volt) }\end{array}$ & Keterangan \\
\hline 5 & 0,0003125 & 2,6 & \multirow{4}{*}{$\begin{array}{l}\text { Dengan } \\
\text { pengutan } \\
\text { Maksimum } \\
1000 \text { kali }\end{array}$} \\
\hline 2,6 & 0,0001625 & 3,2 & \\
\hline 3,2 & 0,0002 & 4,1 & \\
\hline 4,6 & 0,000256 & 4,6 & \\
\hline
\end{tabular}

$$
\begin{aligned}
\text { Iin } & =0,0032 / 16 \mathrm{ohm} \\
& =0,0002 \text { Amper }
\end{aligned}
$$

Vout $=4,1 \mathrm{mV} \times 1000$

$$
=4,1 \mathrm{mV} \text {....... }
$$
dengan

nilai input tegangan maksimum $4,1 \mathrm{mV}$

$$
\begin{aligned}
\text { Iin }= & 0,0041 / 16 \mathrm{ohm} \\
= & 0,000256 \mathrm{Amper} \\
\text { Vout }=4,6 \mathrm{mV} & \times 1000 \\
= & 4,6 \mathrm{mV} \ldots \ldots \ldots .
\end{aligned}
$$

niali input tegangan maksimum 4,6 mV

$$
\begin{aligned}
\text { Iin } & =0,0046 / 16 \mathrm{ohm} \\
& =0,000287 \text { Amper }
\end{aligned}
$$

Tabel.1 : Data Percobaan

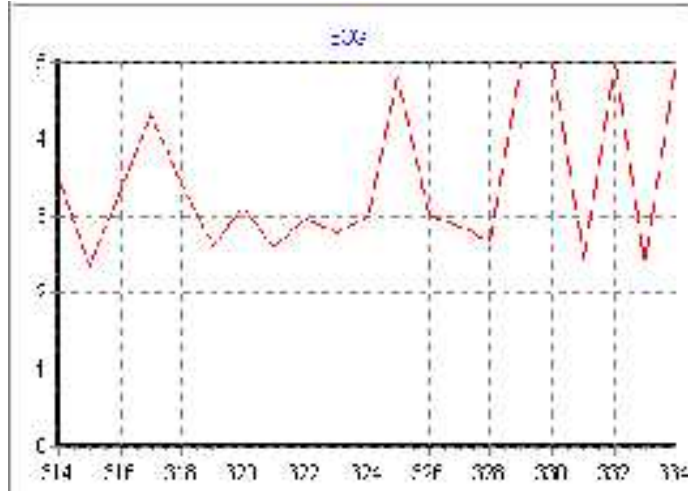

Gambar 9:.Grafik hasil percobaan

Sinyal yang ditangkap oleh penguat haruslah terhindar dari bermacam-macam gangguan, gangguan ini dapat dikarenakan :

- Pengaruh medan magnet pada kabel input, yang mana kabel input berfungsi sebagai antena.

- Pengaruh bahan logam, yakni berupa alumunium.

- Sistem pentanahan.

Output yang dihasilkan oleh rangkaian penguat sekitar 2,2 Volt. Sebelum output terhubung pada rangkaian analog to digital converter, pada output AD624AD dipasangkan rangkain $\mathrm{RC}$ yang berfungsi untuk membuang dan membatasi frekwensi yang lebih tinggi dari 50 hertz.

\section{Pengujian Rangkaian ADC 0809}

Untuk pengujian rangkaian analog to digital converter dapat dilakukan dengan memberikan input tegangan yang bervariasi dengan mempergunakan potensiometer. Indikasi perubahan nilai output yang bergantung pada besaran nilai input dapat dilihat 
dengan memasang led pada masingmasing output dari ADC

Pada prinsipnya rangkaian $\mathrm{ADC}$ ini bekerja berdasarkan prinsip free running mode, dimana pin EOC dan start dihubungkan dan bila kedua pin berlogika 1,maka ia akan terus mengkonversi bilangan kebentuk bilangan digital yakni bilangan biner .

\section{KESIMPULAN}

Elektrokardiogram merupakan alat penditeksi denyut atau isyarat 1strik pada organ tubuh manusia yaitu jantung.Pada rangkaian rancang bangun Elektokardiogram (ECG) ini terdapat pengaruh medan magnet pada kabel input, yang mana kabel input tersebut berfungsi sebagai antena.

Dalam rangkaian ini setiap output yang dihasilkan oleh elektroda (sensor) harus dipasangkan dioda, yang berfungsi untuk mengontrol atau mengamankan sinyal input positif dan sinyal input negatif yang langsung menuju komponen analoq divice (AD624AD).Yang mana komponen analoq divice (AD624AD) berfungsi untuk memudahkan memonitor sinyal yang dihasilkan oleh jantung, sinyal input yang ditangkap oleh analog divice (AD624AD) ini dapat diperkuat sampai 1000 kali.Adapun faktor ganguan-ganguan yang terdapat pada rangkaian ini yaitu : Sistem pentanahan (Grounding), Bahan logam atau alumunium,Pengaruh medan magnet

\section{DAFTAR PUSTAKA}

Sudono Agus,2004,Memanfaatkan Port Printer Menggunakan Delphi. Semarang :SmartBooks

Madcoms, 2003. Seri Panduan Pemrograman Borland Delphi 7 (Jilid 1). Yogyakarta : Andi Offset
Poetra, Abe.2003. Matematika Biner. Ilmu Komputer.com

Kadir, Abdul.2001.Dasar Pemograman Delphi 5 , Yogyakarta: Andi Yogyakarta

Igne Martina Ir, 2001, 36 Jam Belajar Komputer Delphi 5.0. Jakarta : PT. Elex Media Komputindo

Paramono, Djoko. 1999. Mudah Menguasai Delphi 4 (jilid 1). Jakarta: PT.Elex Media Komputindo.

Djoko Pramono. 1999. Mudah Menguasai Delphi 6.0 Jilid I. Jakarta. Komputindo.

Guyton and Hall.1997. Buku Ajar Fisiologi Kedokteran. Jakarta : EGC

J.F. Gabriel dr, 1996, Fisika Kedokteran. Jakarta : Kedokteran.Jakarta 
ISSN: 2085-6989 